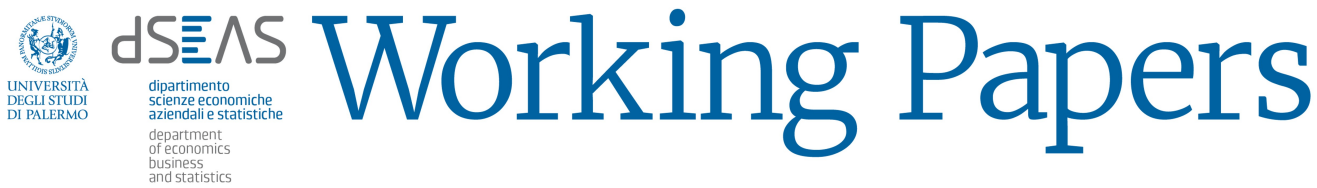

\section{Leisure, Social Capital and Life Turns in Deviant Youth}

\author{
Fabio Massimo Lo Verde
}

\begin{abstract}
The production of social capital in a specific area of everyday life such as leisure time and the different socio-cultural contexts it is experienced in is a very interesting research issue, especially in the light of certain specific meanings of the notion of social capital, such as Bourdieu's or, more recently, Putnam's. Nonetheless, this research issue is scarcely taken into consideration in Italy.

Albeit inexaustively, this paper intends to introduce this issue starting from a brief review on the generation of social capital in youth's leisure time contexts. In the first paragraph I problematize the notion of social capital as referred to leisure time "contexts" as well as analyze either the social capital literature dealing with the modes and experiences of leisure time, or the leisure time literature focusing on the construction of social capital in leisure time contexts. In the second paragraph I discuss some studies regarding the ways in which a particular age range - youth - produces social capital in leisure time contexts. In the third paragraph I focus on some studies regarding the issue of youth's leisure time as a potential "antisocial" time. In the fourth paragraph I introduce the discussion about the little importance given to public leisure in the service provision for youth's leisure time and the consequences determined by that in terms of social capital "erosion". The conclusion offers three metaphors for understanding the trends of leisure time and sociability
\end{abstract}

Keywords Social capital · Leisure Researches · Sociology of leisure

Dipartimento di Scienze Economiche, Aziendali e Statistiche

Università degli Studi di Palermo

viale delle Scienze ed. 13, 90128

E-mail: fabio.loverde@unipa.it 
Riassunto Per quanto il tema della produzione di capitale sociale in un ambito specifico della vita quotidiana come quello del tempo libero e dei diversi modi in cui si declina nei diversi contesti socioculturali sia fra i più interessanti - oltre che da considerarsi un ambito di ricerca germinale di una specifica accezione di capitale sociale, si pensi a quella di Bourdieu o alle più recenti riflessioni di Putnam - esso risulta essere, soprattutto in Italia, scarsamente trattato. Senza pretendere a un'esaustività impossibile da realizzare in questa sede, il presente lavoro intende introdurre il tema a partire da una breve ricostruzione che ha come oggetto la generazione di social capital in contesti di leisure time giovanile. Nel primo paragrafo si problematizza il concetto di social capital in riferimento ai "contesti" di leisure time e si analizza sia la letteratura sul social capital che ha sviluppato alcune piste di ricerca interessanti a partire dalle modalità e dalle esperienze di consumo di leisure time, sia quella sul leisure time che si concentra sulla sua importanza per la costruzione di social capital. Nel secondo paragrafo si analizzano alcune ricerche riguardanti il modo in cui in una particolare fascia di età, quella giovanile, si costruisce social capital in contesti di leisure time. Nel terzo paragrafo si focalizza l'attenzione su alcuni lavori che hanno affrontato il tema del leisure time giovanile come un tempo "a rischio di antisocialità". Nel quarto paragrafo si introduce il tema inerente la scarsa importanza attribuita al public leisure nell'offerta di servizi per il leisure time giovanile e le conseguenze che ciò determina sulla "erosione" di capitale sociale. Nelle conclusioni vengono presentate tre metafore per comprendere il trend della relazione fra leisure time e sociabilità nella postmodernità.

Parole chiave Capitale sociale - Studi sul tempo libero - Sociologia del tempo libero

\section{Introduction}

Three brief anecdotes, all coming from Sicilian common culture, clearly demonstrate how Sicilians picture their island. Two of them feature God and his relationship with Sicily, the third one concerns a cure for its problems.

The first tells about God deciding to play a bad-taste practical joke on someone. After having rotated his index finger in the air for several seconds he shouts "You!", pointing his finger and deciding that this person will be born in Sicily .

God is also the protagonist of the second anecdote. After creating Sicily as an Eden-like land, he has to compensate for such an excessive perfection - so he creates Sicilians!

In the third tale an old man finally finds the remedy to Sicilian problems after unquantifiable meditation - the airplane! In fact there are many learned Sicilians who, having decided not to leave their land permanently by plane, remain in Sicily and assume a constantly laconic expression - sad or bad-humoured, annoyed or bitter - rarely happy. That is perhaps because they mix the heavy cultural load which they feel obliged to carry - and with which they collide - with the well known (at least in Italy) tendency to use the "gattopardesque" categorisation of the supremacy of change to explain the static nature of Sicily.

In this brief note, I present a review of a quite important problem in the literature on the regions of Italy, that is the relation between leisure time and the construction of social capital. 
I also introduce a description of an on-going research project about the "turning points" (Laub and Samspson 1993) in the biography of 40 Sicilian young adults (17-25 years old) who have decided to stop their deviant carrier as a consequence of a particular event (often an arrest), although in their social context it is more frequent that they continue this career. Can the young and intergenerational social capital built in leisure time be a barricade against deviant careers in Sicily too, like in other places of the world? Can this be a better solution than the airplane?

\section{Leisure time and social capital. A short review}

Most of the literature on the creation of social capital within leisure time contexts refers to a notion of social capital in terms of "relational goods" (Arai, Pedlar, 1997; Blackshaw, Long, 2005; Hemingway, 1999); such studies focus both on the availability of leisure time among people belonging to different social groups and on the relation between the amount of leisure time, its allocation and the construction of social capital in the community by means of the activities people do during such time (Rohe, 2004).

In a specific research dealing with the relevance of leisure within the literature on social capital, Glover and Hemingway (2005) - while criticizing the insufficient attention leisure studies have paid to the concept of social capital - show how the study of the definitions and the practices of leisure, combined with the patterns of social capital construction, can contribute to bring to light some important aspects of contemporary sociality.

On the other side, one of the major scholar on leisure, Chris Rojek, states that «Concretely, leisure is one of the main institutions which make it possible to accumulate social capital (2007, p. 324), since it is during this time and in its contexts that reciprocity dynamics can be activated, so supporting the strengthening of social ties and the improvement of community welfare (ibidem; see also Arai, Pedlar, 1997).

Such topic has also been widely treated by one of the best known works on social capital and its "decline" in the United States (Putnam, 2004), which shows how sport associations and leagues - particularly those in the field of bowling - are an important context for supporting social cohesion. Rather than considering leisure time as a secondary field of social life or as a variable depending on other institutional fields of society, such as work, family, etc., Putnam considers leisure time as a field where the basis of the voluntary tendency to form associations and the subsequent social cohesion can be founded. In addition, leisure time is important not only in terms of recreation time, but also in terms of time dedicated to those forms of social exchange which support the construction of stronger ties and norms, shared values, opinions and statements on the world; moreover, Putnam argues that the disposition toward a "lonely" consumption of free time is one of the causes of the «erosion» of social capital in the industrialized societies.

This argument is supported also by other researchers (Hamermesh, 1999, 2000; Gershuny, 2000; Reyes-Garcia et al., 2008), who show that this trend of lonely consumption is raising in 
the developed societies. On the other hand, even in archaic societies there seems not to be a positive relation between the lonely consumption of leisure activities and well-being perceived in terms of satisfaction and good life quality (Reyes-Garcia et al., 2008, pp. 4 and foll.). In fact, the research just mentioned proposes an estimation of the relation between well-being and the two ways of leisure time consumption, i.e. lonely and social, and shows how the latter in particular is able to jointly generate social capital and happiness.

After their analysis of the literature on the relation existing between social capital and leisure time, Glover and Hemingway (2005) argue that a notion of social capital as an extension of the individual involvement into formal and organized social structures, as well as informal associations $^{1}$ - where matters of high "civic" content are treated - can be more easily found within leisure studies. In other words, it is within leisure studies that the second meaning of the concept of social capital - i.e. the "civic" meaning - seems to prevail on the meaning of social capital as a structure of the resources, information, support etc. that can be acquired through the individual participation in a social network.

Referring to this second meaning, Hemingway (1999), for instance, suggests that the amount of social capital that can be generated within leisure time is a function of the kind of leisure activities where the individuals are involved, and of the kind of leisure supply existing in different societies. Obviously, this fact influences the different forms of citizenship that can be generated (ibidem, 154-61) and the subsequent forms of democracy and participation. Somehow this phenomenon would be related to the level of individual independence observed in the creation of a personal leisure rather than in a simple "consumption" practice, and this fact would originate a wider possibility to increase individual "capabilities", as Amartya Sen would say, and favour the creation and reproduction of social capital (see Glover, Hemingway, 2005, p. 395). As the two scholars say, «The question is not if leisure is associated with civically relevant social capital, but what kind of leisure in what kind of setting [...]» (ibidem). Therefore, Glover and Hemingway conclude that it seems obvious that leisure activities can help to increase and/or maintain social capital, but there can also be consumption practices that reduce rather than increase it, including several forms of passive leisure carried out especially through individual practices, as I argued elsewhere (Lo Verde, 2009; Dioguardi, Lo Verde, 2009).

In another study based on the data emerging from an English national survey ${ }^{2}$ - which studied to what extent a greater consumption and variety of leisure activities could generate social capital - Warde e Tampubolon (2002, pp. 163 and foll.) show the existence of a connection between the variety of leisure activities and the formal participation in membership groups, in the sense that the number of leisure activities seems to increase as the involvement in associative activities increases, including, of course, those activities directed towards the management of leisure services (sports clubs, recreation clubs etc.)

As the authors argue, according to a view à la Putnam, the involvement in fun activities and hobbies seems to increase as individual social capital increases, even if the variation in

1 Among such informal associations the two scholars include the recent network of online discussion groups.

2 This survey is the British Household Panel Survey started in 1991. 
the growth of such activities is positively related to education qualifications. People who are members of formal associations spend less time for each activity, since the number of the activities is greater; however, on the other hand, such people show high level of involvement, for instance, in terms of how frequently each activity is done. In addition, the growth of public and civic participation seems to be associated with the growth of the recreational activities practiced in private settings (ibidem, p. 166). According to these two authors, this would seem to disconfirm the theory by Hirschman (1983) that consumption and political activism are often conflicting. On the other hand, if we accept the theory that the total volume of participation in associations is strongly correlated with political activism, it would seem that whoever is politically active is simultaneously strongly involved in various forms of recreational activities. In the same study, Ward and Tampubolon analyze the relationship between friendship networks and the types of recreational activities practiced.

According to this research people who are members of caregiver associations tend to have a tendency to share different friends from themselves in terms of leisure choice, lifestyles and so on. As Ward and Tampubolon argue, «This might imply that people take some notice of the classic agony aunt recommendation that if you are lonely or sad, and haven't got many friends, then join a club». (Ibidem, p.169). However, people who generally have very different friends would also tend to have fewer friends. But this fact would reduce the participation in formal groups, far from the reverse situation. Relating to leisure, one is likely to decide to take part in formal groups if he/she cannot share activities with his/her friends. But it could also be plausible the reverse argument that the associations include very different people, in terms of age, gender, educational qualifications etc., and this fact would consequently facilitate their mixing with other people who differ by nature.

According to the researchers there is no connection between all these things and the presence of social capital, since the embedding into friendship-based networks would seem to have weak effects on the participation in the activities within associations and, consequently, on a particular dimension of social capital, the civic one. In fact, the distance among friends is more sensitive to the number of activities that one can do than it is to their frequency. In other words, if one has friends who are so much like him/her, he/she will probably prefer to do more types of activities - perhaps because he/she shares them with such friends - than doing the same activity more frequently.

\section{Social capital and leisure time among young people}

Our research question is how social capital among young people can be generated and, moreover, how it can be developed or eroded through their leisure activities.

Scholars point out that adults and policy makers usually consider leisure time among young people as an "empty" time, and consequently - however without ever specifying this connection - as risky both for themselves and the adults they live with in different communities. Equally often scholars argue that leisure time is important in the organization and life of the community. 
On the one hand, there are other studies focusing on youth participation in activities that can generate social capital, civic-mindedness etc. (McFarland, Thomas, 2006; Helve, Bynner, Holland, 2009) ${ }^{3}$ - such as activities like participation in voluntary associations. Also international organizations recognize the importance of leisure time in the development of communities (United Nations, 2004, pp. 214ss.); on the other hand, however, little research has been carried out so far about the connection between the activities done by young people in their leisure time and the construction of trust networks that are fundamental for generating social capital. Mainstream studies predominantly deal with the lack of social capital and the relation between such lack and the diffusion of deviant behaviours (Mahoney, Stattin, 2000; Deuchar, 2009) or criminal ones (Hagan, McCarthy, 1997).

As some studies show, the analysis of how social capital can be generated among young people is important since those who participate in youth groups - and thus tend to generate a specific form of social capital - are more likely to maintain this practice in adulthood too. In addition, high levels of social trust among adults are positively correlated to high levels of social trust during their teen years (Stolle, Hooghe 2004, p. 431). Briefly, according to Vesely (2006) the study of social capital among young people represents a "window on the future" of societies, in spite of the problem of the low "levels of stability" in the transition from one generation to another.

Finally there is a great amount of research on a particular kind of youth free/leisure time that can be defined as "antisocial". Such research includes, for instance, the studies dealing with the different kinds of gambling played by teenagers and young adults, or the "normalization" of drugs consumption (Parker, 1998; Griffits, 1995). In general, these studies consider leisure time as a "dangerous time", partially or entirely beyond the adults' control, with a high level of risk that young people may enter/stay in deviant groups, so generating deviant or illegal leisure (Rojek, 1999) rather than forms of pro-sociality coping.

One of these studies (Mahoney, Stattin, 2000) shows that the involvement of teenagers and young adults in "more structured" activities ${ }^{4}$ as well as the presence of an adult as a leader (coach, trainer, etc.) were negatively correlated to antisocial behaviours; whereas "less structured" activities - such as joining youth community centres or watching television - were positively correlated to antisocial activities. In addition, adults who had taken part in less structured activities during their youth used to choose deviant individuals as their friends, have difficult emotional ties with their parents and get a lower support to their activities from operators (ibidem, p. 114ss.).

\footnotetext{
3 About Italy see Bettin Lattes, 2001; Prandini, Melli, 2004, Cesareo, 2003, 2005; Donati, Colozzi, 1997; and IARD Reports (Buzzi, Cavalli e de Lillo, 1997, 2002, 2007).

4 The expression «more structured activities» refers to those activities that need to be learned through socialization processes and that allow individuals to gain specific abilities, namely serious leisure activities (Stebbins, 2007; see also Caldwell, Smith, 2006, p. 402), such as the activities in the field of sport, music, art, handicraft etc.
} 
Focusing on a "criminological" view, Caldwell and Smith (2006, p. 399) have recently classified the studies about the relation between leisure and youth deviant careers into four lines of research:

a) A line considers free/leisure time as time "to be filled". Therefore the time that "is filled" with "pro-social" activities cannot be filled with deviant ones.

b) Another line of research looks at free/leisure time as connected with activities done with a deviant peer group: some activities have higher chances of generating deviant behaviours or are typical of deviant subcultures; therefore it is important to identify the genesis of such activities, to analyze the context where they were generated etc.

c) A further line analyzes leisure time in connection with a higher or lower level of "structured" activities: the time dedicated to those activities that are less organized, informal or with no supervision by adults is more likely to provide the context for deviant behaviours, unlike the time spent in activities that are supervised by adults or are more structured. There are opposite views especially in this case. For instance, many scholars agree that unstructured activities let people, especially teenagers, experience new roles, ideas and behaviours, hence supporting their social identity formation (Kleiber, 1999) as well as the development of an autonomous transition process to adulthood.

d) Finally, a line of research looks at the interaction between the individual and the environment as a paradigmatic element: to have self-control and share norms and conventional activities prevent from adopting deviant behaviours.

Anyhow, in spite of the unsystematic, often fragmented and sometimes contradictory nature of the studies on the contribution that leisure activities and contexts can offer to the construction of social capital and to networks of shelter pursuing precautionary or rehabilitating aims (Williams, Walker, 2006; Williams, 2009), the topics on such contribution are partially treated also with respect to the biographies of young people and teenagers who are at risk of social exclusion or who already live in marginal contexts or environments; therefore these topics are usually covered by a literature looking at the importance of institutional "networks", and noprofit organizations that benefit from the state intervention towards some social classes ${ }^{5}$ or that live within re-educational institutions for teenagers outlaws.

Beyond the problems existing in data survey and data capture procedures on the different leisure activities (see Gershuny, 2000), the fact is that a different amount of time is spent on different activities that have a higher sociability nature and this situation can be considered as a consequence of the way free/leisure time is institutionalized within different cultures. Nowadays such way is partially function of the supply, especially the supply of places and contexts for leisure time provided by the public sector, which is less and less capable of "competing with"

5 With reference to such interventions made in Italy, see Sanicola, Piscitelli, Mastropasqua (eds.), 2002. 
a private sector that tends to produce leisure services and goods to be experienced by single individuals in private places (Lo Verde, 2009).

As a temporary conclusion, it can be argued that leisure time can possibly be, under specific conditions, an important locus for social capital generation within peer groups and young adults. Togetherness and peer complicity, although more in a bonding rather than a bridging way, can be a supportive and relational resource for young individuals. Is it possible "to trigger" life turns decision in deviant young adults who spend their leisure time in occasional/frequent illegal practices? And how can this leisure time be turned from illegality to the construction of social integration?

In our still on-going research we have focussed on two concepts, discontinuity and reflexivity, following Archer's typology of reflexivity (Archer, 2003). We want to know how the social relation system may contribute to a decision of discontinuity and what role reflexivity plays in this decision. We have interviewed 40 young adults aged between 17 and 25, asking them to narrate their decision of life change to see whether this decision was somehow related to some specific form of reflexivity. Moreover, we have compared these interviews with the opinions of social workers and teachers as expressed during three focus groups. We are currently working on the analysis of the data collected through such interviews and focus groups. From a first superficial analysis, there seems to be evidence that leisure time is a problematic dimension for these young adults (how and where to spend it, with whom, for how long, and so on). There also seems to be evidence that structured activities, daily engagements, the presence of an adult "coach" or "leader" or "guide", the shifts or "fractures" with the usual daily social context, may contribute to the reduction of the time spent in illegal leisure practices. Interestingly, this kind of evidence seems to bring Sicilian young adults much nearer to other global cities' young adults in the world. There is indeed room for new general hypotheses and research about leisure time, social capital and deviant young adults.

\section{References}

Arai S., Pedlar A. (1997), Building communities through leisure: Citizen participation in a healthy communities initiative, in «Journal of Leisure Research», vol. 29, n. 2, pp. 167-182.

Archer M. S. (2003), Structure, Agency and The Internal Conversation, Cambridge University Press, Cambridge.

Bettin Lattes G. (a cura di) (2001), La politica acerba. Saggi sull'identità civica dei giovani, Rubbettino, Soveria Mannelli (CZ).

Blackshaw T., Long, J. (2005), What's the big idea? A critical exploration of the concept of social capital and its incorporation into leisure policy discourse, in «Leisure studies», vol. 24, n. 3, pp. 239-258.

Buzzi C., Cavalli A. De Lillo A., (a cura di) (2002), Giovani del nuovo secolo. Quinto rapporto IARD sulla condizione giovanile in Italia, Bologna, Il Mulino. 
Buzzi C., Cavalli A. De Lillo A., (a cura di) (2007), Rapporto giovani. Sesta indagine dell'Istituto IARD sulla condizione giovanile in Italia, Il Mulino, Bologna.

Buzzi, C., Cavalli, A. De Lillo, A, (a cura di) (1997), Giovani verso il Duemila. Quarto rapporto IARD sulla condizione giovanile in Italia, Bologna, Il Mulino.

Caldwell, L. L., Smith E. A. (2006), Leisure as a context for youth development and delinquency prevention, in «Australian and New Zealand Journal of Criminology», Vol. 39, n. 3, pp. 398-418.

Cesareo V. (a cura di), I protagonisti della società civile in Italia, Rubbettino, Soveria Mannelli (Cs) 2003.

Cesareo V. (a cura di), Ricomporre la vita. Gli adulti giovani in Italia, Carocci, Roma 2005.

Coleman J. S. (1990), Foundation of Social Theory, Harvard University Press, Cambridge MA

Deuchar R. (2009), Gangs, Marginalised Youth and Social Capital, Trentham Books, London

Dioguardi V., Lo Verde F. M. (2009), Non solo "quel che resta del giorno". Un'analisi comparativa del consumo di tempo libero in Europa, in «Studi di Sociologia», 4, pp. 345-381.

Donati P., Colozzi I. (a cura di) (1997), Giovani e generazioni. Quando si cresce in una società eticamente neutra, il Mulino, Bologna.

Gershuny J. (2000), Changing Time. Work and leisure in post-industrial society, Oxford University Press, Oxford.

Glover T. D., Hemingway, J. (2005), Locating leisure in the social capital literature, in «Journal of Leisure Research», vol. 37, n. 4, pp. 387-401.

Griffiths M. (1995), Adolescent gambling, Routledge, London.

Hagan J., McCarthy B. (1997), Mean Streets: Youth Crime and Homelessness, Cambridge University Press, New York.

Hamermesh, D.S. (1999), The timing of work over time, in «The Economic Journal» n, 109, pp. 37-66.

Helve H., Bynner J. (Eds.) (2007), Youth and Social Capital, Tufnell Press, London.

Hemingway J. (1999). Leisure, social capital, and democratic citizenship, in «Journal of Leisure Research»,vol. 31, n.2, pp. 150-165.

Hirschman A. O. (1983), Felicità privata, felicità pubblica, Il Mulino, Bologna.

Holland J. (2009), Young people and social capital. Use or abuse, in «Young», vol. 17, n. 4, pp. 331-350.

Kleiber D.A. (1999), Leisure experience and human development: A dialectical interpretation, Basic Books, New York.

Laub J. H., Sampson R. J. (2003), Turning Points In The Life Course: Why Change Matters To The

Study Of Crime, in «Criminology», Vol. 31, n.. 3, pp. 301-325.

Lo Verde F. M. (2009), Sociologia del tempo libero, Laterza, Roma-Bari. 
Mahoney J. L, Stattin H. (2000), Leisure activities and adolescent antisocial behaviour: The role of structure and social context, in «Journal of Adolescence»n.23, pp. 113-127.

McFarland D. A., Thomas, R. J. (2006), Bowling young: How youth voluntary associations influence adult political participation, in «American Sociological Review», vol. 71, n. 3, pp. 401-425.

Parker H. (1998), Illegal leisure: the normalization of adolescent recreational drug use, Routledge, London.

Prandini R., Melli S. (2004), I giovani e il capitale sociale dell'Europa futura, Franco Angeli, Milano.

Putnam R. D. (2004), Capitale sociale e individualismo. Crisi e rinascita della cultura civica in America, Il Mulino, Bologna.

Reyes-García V., Godoy R., Vadez V., Ruíz-Mallén I., Huanca T., Leonard W., McDade T., Tanner S. (TAPS study Team), (2009), The pay-offs to sociality: Do solitary and social leisure relate to happiness? in «Human Nature. An Interdisciplinary Journal with Biosocial Perspective», Vol. 20, n. 4, pp. 431-446.

Roberts K. (1983), Youth and Leisure, Allen \& Unwin, London.

Rohe W. M. (2004), Building social capital through community development, in «Journal of the American Planning Association», n. 70, pp. 143-144.

Rojek C. (1999), Deviant leisure: The dark side of free-time activity, in Jackson E.L., Burton T.L. (Eds.), Leisure studies: Prospects for the twenty-first century, Venture, State College PA, pp. 81-96.

Rojek C. (2007), An Outline of the Action Approach to Leisure Studies, in Page S. J., Connell J. (eds.) (2007), Leisure Studies, Routledge, London, 4 voll., vol. I, pp. 321-335.

Sanicola L., Piscitelli D., Mastropasqua I. (a cura di) (2002), Metodologia di rete nella giustizia minorile, Liguori, Napoli.

Stebbins R.A. (2007), Serious Leisure, Transaction Publisher, New Brunswick, New Jersey.

Stolle D., Hooghe M. (2004), The Roots of Social Capital: Attitudinal and Network Mechanisms in the Relation between Youth and Adult Indicators of Social Capital, in «Acta Politica», vol. 39 , n. 4, pp. 422-441.

Veselý R. (2006), Reproduction of Social Capital: How Much and What Type of Social Capital Is Transmitted from Parents to Children? Paper prepared for Trust, Reciprocity and Social Capital The 2006 Ratio Colloquium for Young Social Scientists, Stockholm, August 2526, 2006, pubblicato in parte in Ratio Working Papers No 105, from The Ratio Institute in http://econpapers.repec.org/paper/hhsratioi/0105.htm.

Warde A., Tampubolon G. (2002), Social capital, networks and leisure consumption, in «The Sociological Review», vol. 50, n.2, pp. 155-180

Williams, D J (2009), Deviant leisure: Rethinking "the good, the bad, and the ugly", in «Leisure Sciences», n. 31, 207-213.

Williams, D J, Walker, G. J. (2006), Leisure, deviant leisure, and crime: Caution: Objects may be closer than they appear, in «Leisure/Loisir», n. 30, pp. 193-218. 